I Report

Y/OWI/SUB-77/45707

September 1977

\title{
POSTDECOMIMISSIONING MONITORING FEASIBILITY STUDY FOR RADIOACTIVE WASTE REPOSITORIES IN ROCK SALT FORMATIONS
}

This report was prepared by Envirosphere Company, EBASCO Services Incorporated under subcontract $62 Y-45707 V$ with Union Carbide Corporation, Nuclear Division, under contract number W-7405-eng-26 with the Energy Research and Development Administration. The subcontract was administered by the Office of Waste Isolation.

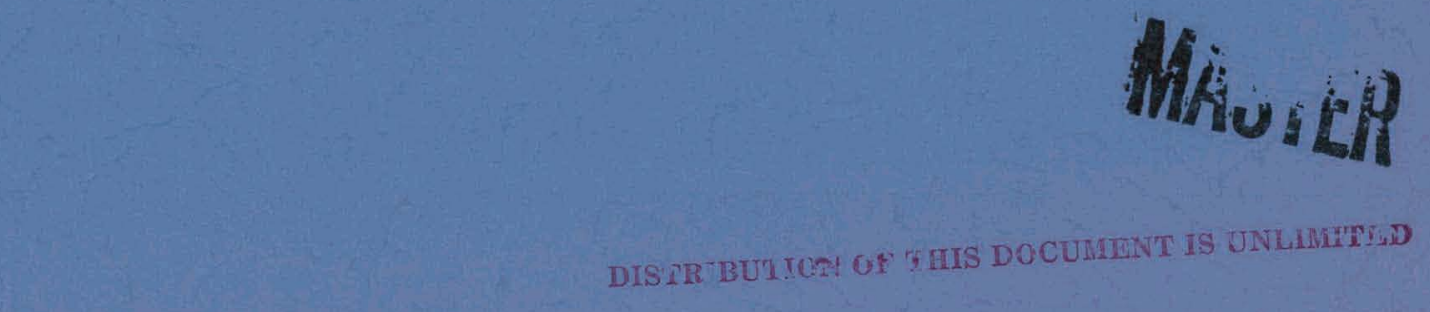

\section{envirosphere company}




\section{DISCLAIMER}

This report was prepared as an account of work sponsored by an agency of the United States Government. Neither the United States Government nor any agency Thereof, nor any of their employees, makes any warranty, express or implied, or assumes any legal liability or responsibility for the accuracy, completeness, or usefulness of any information, apparatus, product, or process disclosed, or represents that its use would not infringe privately owned rights. Reference herein to any specific commercial product, process, or service by trade name, trademark, manufacturer, or otherwise does not necessarily constitute or imply its endorsement, recommendation, or favoring by the United States Government or any agency thereof. The views and opinions of authors expressed herein do not necessarily state or reflect those of the United States Government or any agency thereof. 


\section{DISCLAIMER}

Portions of this document may be illegible in electronic image products. Images are produced from the best available original document. 
POSTDECOMMISSIONING MONITORING FEASIBILITY STUDY FOR

RADIOACTIVE WASTE REPOSITORIES IN ROCK SALT FORMATIONS

ENVIROSPHERE COMPANY

19 RECTOR STREET

NEW YORR, NEW YORK 10006

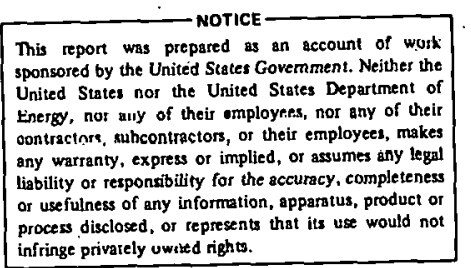

infringe privarely uwsed rights.

SEPTEMBER 1977

This report was prepared as an account of work sponsored by the United States Goverment. Neither the United States nor the Energy Research and Development Administration, nor any of their employees, makes any warranty, express or implied, or assumes any legal liability or responsibility for the accuracy, completeness or usefulness of any information, apparatus, product or process disclosed, or represents that its use would not infrlige privatcly owned rights. 


\section{FOREWORD}

This report was prepared under a subcontract with Union Carbide Corporation, Nulcear Division, a U.S. Energy Research and Development Administration (ERDA) contractor. This subcontract was administered by the office of Waste Isolation (OWI), program manager for ERDA's National Waste Terminal Storage (NWTS) Program. The principal objective of the NWTS Program is to provide facilities (waste repositories) in various deep geologic formations at multiple locations in the United States that will safely dispose of the radioactive waste generated by commercial operations and that must be delivered to a federal repository for terminal storage. These federal repositories will be 1 icensed by the Nuclear Regulatory Commission (NRC).

After a repository has been filled with radioactive waste to the extent planned and the underground rooms containing this waste backfilled with material originally mined from these rooms, the repository will be decommissioned. This decommissioning is expected to include sealing of al1 shafts and penetrations into the geologic disposal horizon and removal of surface facilities. Although the fundamental rationale for deep geologic waste disposal is based upon the consideration that this method of disposal eliminates the necessity for any direct control after the repository is decommissioned, as part of a program of continuing surveillance of the site it is expected that a postdecommissioning monitoring program will be required by regulatory agencies. This postdecommissioning monitoring program will have as one of its objectives the verification that the repository is performing as predicted. This verification is expected to be achieved through a program of periodic measurements in the area of the repository. The nature of the required measurements will depend on the geologic and hydrologic characteristics of the site location. For example, they would in most instances include measurements of chemical and radionuclide concentrations in ground water at various depths at selected locations in the vicinity of the repository. If it is determined that the repository is not performing as predicted then a determination will be made as to the required remedial artinn, if any. In this regard, records of the location of all waste disposed of in the repository will be kept so it can be excavated and removed if necessary.

Although the exact nature of a postdecommissioning monitoring program will depend upon the geologic and hydrologic characteristics of a particular site and will not be detailed until the time approaches for it to be implemented (early in the twenty-first century for the first repository, after its expected 25-40 year operating lifetime) it is desirable to initiate planning at an early stage. This early planning is particularly appropriate so that the general requirements of a postdecommissioning monitoring program can be considered in establishing and carrying out the operational monitoring program. Therefore, to provide guidance in planning, OWI has initiated this preliminary evaluation of a postdecommissioning monitoring program for a waste repository located in a rock salt formation. This report represents the independent suggestions of the subcontractor retained for that purpose. The assumptions, views, and conclusions expressed in this document are those of the authors and are not to be interpreted as those of Union Carbide Corporation, Nuclear Division, or of ERDA. 


\section{ABSTRACT}

A preliminary evaluation of the postdecommissioning monitoring of a radioactive waste repository facility established in bedded or domal salts has been performed. The results of the study indicate that while some general conclusions as to monitoring feasibility can be made, any detailed evaluation of monitoring program effectiveness must be based upon evaluations performed for a specific site. A wide range of presently available instrument packages could be deployed in surface, borehole, or buried locations to monitor key radiological, geological and hydrological properties of the repository and its surroundings after decommissioning. If sufficient sensitivity can be obtained, these measurements, when correlated with analytical modeling results, could provide a description of repository integrity, a1lowing further extrapolations of expected behavior. Definitive projections of sensitivity and thus the applicability of presently available instrumentation cannot be made, however, without reference to specific site characteristics or without the benefit of regulatory criteria.

Due to reliability considerations and technologica1 limitations, it appears that any monitoring program should be based upon sensors located either at the surface or in accessible boreholes or subsurface galleries which do not penetrate the repository containment strata. Because of this feature of retrievability. of the sensing devices such a system could be maintained for an indefinite period of time. Because aquifers may serve to transport radioactive releases due to either accident or non-accident events, aquifer monitoring should form a critical part of such a system. While it appears that technology could be developed to provide for the initial placement of buried sensors without need for hard wire contacts for either power supply or data transmission, such communication would be realistically limited to a relatively short time period after decommissioning because of the severe environmental conditions present in the repository and its surroundings.

It is recomended that plans for postdecommissioning monitoring be given further consideration during the specification of site investigation and preoperation programs. Particular effort should be expended in (1) developing regulatory criteria appropriate to the decommissioned repository;

(2) defining what constitutes a significant variation in monitorable parameters and (3) comparing these variations and regulatory criteria with instrument sensitivities under actual site conditions. 
FOREWORD

ABSTRACT

LIST OF TABLES

vi

I. INTRODUCTION

A. Background/Study Definition 1

B. Basic Assumptions 2

C. Definition of Important Terms 3

1. Monitoring Periods 3

2. Nature of Events . 4

D. General Nature of the Study 4

E. Organization of Report $\quad 4$

II. POTENTIAL FAILURE MODES

A. Failure Modes 6

B. Parameter Selection 8

1. Radioactivity Measurements ?

2. Hydrological Mea surements 9

3. Geological/Geophysica1 Measurements 10

III. CONCEPTUAL APPROACH TO POSTDECOMMISSIONING MONITORING $\quad \therefore \quad 11$

A. Monitoring Emplacements 11

1. Open Borehole Monitoring . 11

2. Buried Monitors 12

3. Surface Mont toring 13

4. Subsurface Moñleoring Gallerles 13 
TABLE OF CONTENTS (Cont'd)

B. Deployment of Monitors 14

IV. MONITORING TECHNIQUES AND INSTRUMENTATION 16

A. Surface Monitoring 16

1. Geologica1 and Geophysical Techniques 16

Selsmic Methods 16

Electrical Measurements $\quad 18$

$\begin{array}{ll}\text { Measurement of Ground Displacement } & 19\end{array}$

2. Radiological Detection 20

B. Open Borehole Monitoring 20

1. Geological and Geophysical Investigations 20

Acoustic Logging 23

Electrica 1 Logging 23

Radioactivity Logging 23

2. Hydrologica1 Logging 24

Fluid Movement Logging $\quad 24$

Ground Water Conductivity 25

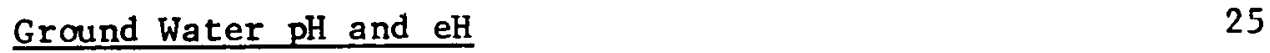

Ground Water Velocity $\quad$. 25

Ground Water Temperature $\quad 25$

Ground Water Salinity $\quad 25$

Ground Water Pressures and Leve1s. 25

3. Radiological Logging 25

Gamma Scintillation Crysta1 Detector - Spectrometer $\quad 26$ 
TABLE OF CONTENTS (Cont' $d$ )

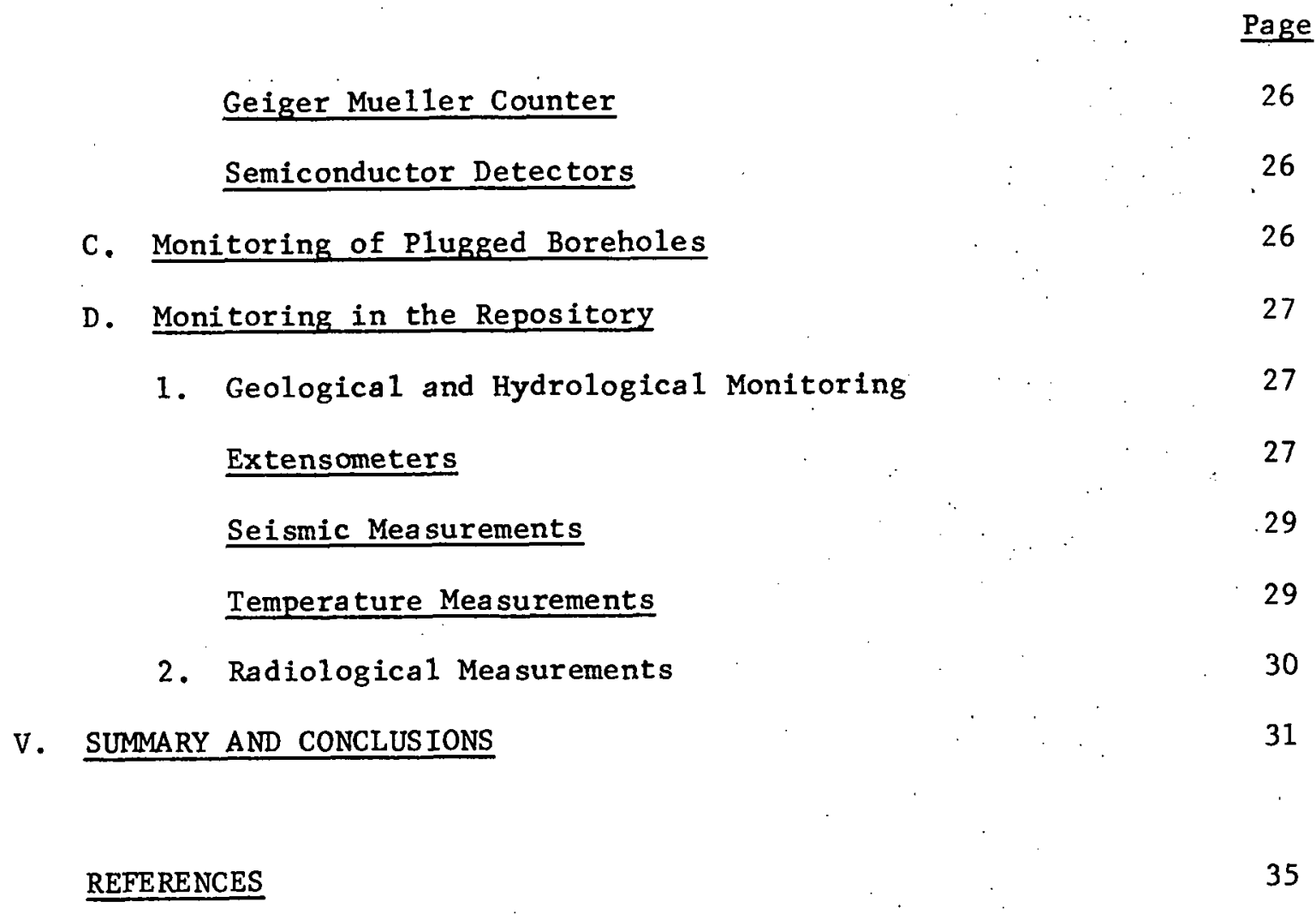




\section{LIST OF TABLES}

Number

Title

Page

$\begin{array}{ll}\text { IV-1 } & \text { Surface Monitors } \\ \text { IV-2 } & \text { Subsurface Monitoring } \\ \text { IV-3 } & \text { Buried Monitors } \\ \text { V-1 } & \begin{array}{l}\text { Failure Warning System Effectiveness } \\ \text { Non-Accident Mode Failures } \\ \text { V-2 }\end{array} \\ & \begin{array}{l}\text { Failure Warning System Effectiveness } \\ \text { Accident Mode Failures }\end{array}\end{array}$

17

21

28

33

34 
I. INTRODUCTION

\section{A. Background/Study Definition}

Present plans for the National Waste Terminal Storage Program call for the establishment of radioactive waste repositories in bedded and/or domal rock salt (Zerby, 1976). During the initial operational phase of a waste repository, wastes will be stored in a retrievable form and it is expected that an extensive monitoring program will be implemented. After decommissioning of the facility, consisting of backfilling and plugging al1 shafts and boreholes as well as removal of surface facilities, the wastes would be in essentially irretrievable form and would be recoverable, if at all, only through an extensive reclamation effort. Although the facility will be decommissioned only if it has been determined with high assurance that the repository would maintain its integrity for the required containment period, it may be necessary for either confirmatory reasons or in recognition of regulatory requirements to establish a monitoring program for the decommissioned phase of the facility.

Under the assumption that postdecommissioning monitoring will be required, it is appropriate to ask what monitoring procedures could be implemented and for what time period. The present report summarizes the results of a preliminary study addressing these fundamental questions from a technical viewpoint for a repository located in rock salt.

Clearly, an effective monitoring program must be thoroughly thought out, combining state-of-the-art expertise in monitoring techniques, instrumentation and data transmission with the results of analytical modeling of significant repository effects and applicable regulatory criteria. The installed system must be capable of obtaining as much information as needed on subsurface conditions without compromising the integrity of the facility. Furthermore, the system should be able to monitor the effects of the storage facility on the environment, as well as the effects of the enviroment on the facility.

A complete program incorporating a proper consideration of all these potential areas of concern may take years to fully develop. Such a program should be compatible with, if not based upon, the preconstruction and operating stage monitoring programs. Realistically the needs of a postdecommissioning program should be reflected in the design and specification of these precursory programs. Within the limited scope of the present study, we have attempted to identify some of the considerations attendant to monitoring system development and thus provide a background for a more detailed consideration of a postdecommissioning program. In this regard our specific objectives have been to:

1) Briefly describe the major characteristics of the Waste Repository Facility concept and identify factors potentially affecting the long-term stability of its isolation capabilities. 
2) Enumerate those rock, ground water, radiation and other physical or chemical parameters having potential for providing reliable information as to the status of the integrity of the waste isolation barrier.

3) Outline monitoring techniques and identify instrumentation for obtaining information on the parameters identified in item 2 including an identification of problems associated with the transmission of power to, and information from, subsurface sensing locations.

4) Discuss, to the extent possible, placement of monitoring instrumentation.

\section{B. Basic Assumptions}

Our evaluations have been based upon two primary constraints which are believed necessary to provide assurance that a monitoring program can be successfully implemented. While general in nature these constraints provide the basic guidelines for development of a detailed program. These basic guidelines are the following:

1) The monitoring system must not compromise the integrity of the facility.

2) The monitoring system should be capable of being installed using instrumentation, power supply, and data transmission packages presently available, or capable of being developed with a modest extension of present capabilities.

These constraints impose seriously upon program specification. The first constraint effectively requires that the system not rely upon hard wire links to the repository itself or the salt immediately enveloping the repository. At some specified distance from the repository, presently proposed as a three (3) mile radius (Zerby, 1976), it may be possible to pierce the confining lithologies with hard wire links and/or shafts. These restrictions are proposed to limit the potential for creating a ground water path between the outside environment and the sealed repository as a result of the corrosion of wire links. In effect, these constraints force one to look for indicators of repository stability which can be detected with sufficient sensitivity by monitors located relatively distant from the repository.

The constraint on technology application also requires a more detailed look at those systems which operate from outside the repository. While it is possible that in-repository sensors meeting the requirements of the first constraint can be developed, the use of such sensors is not realistically indicated for anything other than a short time period after 
decommissioning. The effect is once again to place emphasis for monitoring on systems that view the repository as a "black-box" viewed from outside.

\section{Definition of Important Terms}

In the course of the study it has been necessary to make use of a number of terms which by their very nature can have ambiguous meanings. Use of such terms can, however, have an important bearing on the interpretation of results. The principal areas which are subject to ambiguous interpretation are the descriptions of monitoring periods and the distinction between accident and non-accident events. Thus, while definitiveness is by no means possible, we have attempted to adhere to the following definitions of those key terms throughout this report.

\section{Monitoring Periods}

Given the time scale on which isolation must be assured, any discussion of monitoring program implementation can be approached in relative terms only. While it is possible to divide the postdecommissioning time period into short, intermediate, and long periods, and attempt to relate these durations to occurrences expected during the respective periods (Witherspoon, 1977), the present discussion explicitly considers only two time periods. These periods reflect the expected lifetimes of monitoring equipment reliability rather than the time period over which important repository effects may be observed. The "short term" period refers to that time period during which it is reasonable to assume that in-repository or buried instruments will function and transmit useful information on the status of the repository integrity. At the present level of detail, it is unimportant whether this period is 5 years or 20 years, only that its passage signals the termination of one part of the monitoring system. As it is not possible to specify any definitive time increment with this period a range of 5-20 years is typically used In the report. In subsequent studic when the epecific goals of the program are further defined, the actual time period will, of course, take on more importance as one attempts to correlate monitoring system results with analytical study results for the purpose of extrapolating expected behavior.

Complementing this definition of "short term" is the use of "long term" to connote that period during which monitoring will be carried on essential1y by monitors located outside of the sealed repository environment. In this context it becomes unnecessary, as in the short term case, to specify an upper limit to the monitoring period although realistically it is difficult to conceive of monitoring continuing for periods exceeding hundreds of years. A decision to terminate monitoring would be solely in the hands of the governing body which is responsible for maintaining the monitoring program. Since these system components are essentially retrievable and subject to modification and improvement, the program could remain in effect as long as deemed required by the governing agencies. 


\section{Nature of Events}

Confusion is also evident in attempting to differentiate between nonaccident, or accident events. As such, to the degree possible, we have attempted to make the discussion independent of any such distinction. When the terms are encountered in this report, non-accident (quiescent) conditions refer to slow geological occurrences such as creep or salt dissolution which may take place gradually over a relatively long time period. On the other hand, accident (non-quiescent) events are less protracted in nature and may include events such as faulting which could provide pathways for ground water ingress into the repository.

D. General Nature of the Study

This preliminary study presages the considerable problems which will be incurred in detailed program specification if site conditions and regulatory criteria are not specified beforehand. Lacking a detailed site description, a facility design, and the results of analytical modeling studies, it is not possible to uncover all the effects which may need monitoring. Since the heart of any monitoring program must be timely detection with requisite sensitivity of radionuclide releases, or of events which may precede radionuclide release to the environment, an effective system can only be designed knowing the range of impacts which can be expected to be significant and then determining whether instrumentation-exists to allow measurement at that level. In the present case, this step is precluded without recourse to specific defining conditions, and thus any conclusions as to instrument applicability must necessarily be tentative in nature. The necessary development is that the study itself can only recommend courses of action that could be followed, rather than recommending what should be implemented. The distinction is, of course, vital and is used throughout the report. As regulatory criteria are developed and additional information relative to a specific site and facility design become available, the list of "could" items can be reduced to a smaller number of "should" items.

\section{E. Organization of Report}

The intention of the proposed organization is to allow for the exposition of thoughts provided in Section $A$ in a logical manner realizing the 1 imitations and/or clarifications noted in Sections B, C and D above. Accordingly, Section II of the report contains a summary of the events which could be addressed by the monitoring program, followed by an exposition of the parameters that are considered most capable of reflecting these conditions. Section III contains an introduction to a monitoring system approach which outlines, to the extent possible, the requirements for sensor location and density. This discussion serves as a background for the consideration of monitoring hardware contained in Section IV. The report finishes with a recapitulation of primary conclusions and recommendations for further work in this area.

While the intention of this organization was to separate information into self-contained packages, this could not be accomplished completely 
due to the overlap in subject material. For example, any discussion of sensor deployment in a combination of surface, borehole and buried instrument packages must be tempered by the fact that buried deployment is seriously impacted by the availability of power and transmission equipment. As a result it is difficult to discuss instrument deployment and monitoring techniques independent of instrument types and methods of data transmission. The summary conclusions contained in Section $V$ should be sufficiently broad to resolve any confusion as to any major points which may have developed due to this overlap. 
II. POTENTIAL FA ILURE MODES

A consideration of postdecommissioning monitoring must be based primarily upon an evaluation of the modes by which containment integrity (the confining geologic formation) may be breached and the mechanisms by which radionuclides may ultimately reach the environment. These evaluations provide the basis for an understanding of what must be monitoried, thus setting the stage for a consideration of how monitoring can be done. Because of the critical need to insure repository integrity for long periods of time, these potential failure modes and transport mechanisms have received significant attention in the literature (Gera and Jacobs, 1972; Claiborne and Gera, 1974; Bishop and Mirag1ia, 1976)。Although it is not necessary to conduct an all-inclusive review of such potential mechanisms within the context of the present study, a basic review is in order. In this light, the general classification of Bishop and Miraglia (1976) is suitable and provides the basis for the following discussion.

In reviewing this information it is important to note two factors which are central to monitoring system deployment; these are: (1) monitoring may consist of detecting variations in geological and hydrological parameters which may be indicative of potential radionuclide releases in the future; and (2) monitoring may consist of detecting radionuclide levels which are directly indicative of repository failure occurring sometime in the past. While the relative importance of these two factors is not resolved in the present discussion (such resolution will be possible only when a11 the factors relative to establishing monitoring criteria are in hand), it is sufficient to note that both radiological and geological/hydrological parameters can yield information on the status of repository integrity. Section II A discusses the initiating events while Section II B considers the parameters to be monitored in somewhat more detail.

\section{A. Failure Modec}

Bishop and Miraglia (1976) have classified events potentially leading to repository failure as follows:

Type 1: Natural rapid events uninfluenced by man (e.g. meteorite impact)

Type 2: Natura1 geological and/or hydrologica1 events or processes independent of the existence of the repository (e.g. regional faulting, erosion)

Type 3: Geological and/or hydrological events or processes caused by the presence of the repository (i.e. those stimulated by the presence of radiation and thermal sources)

Type 4: Human actions directly or indirectly affecting the repository (e.g. acts of war, sabotage, exploration for mineral resources) 
It is unrealistic to assume that a properly deployed monitoring system should be capable of forewarning potential failures arising from each of these types of occurrences. While in a sense a program should be sufficiently diverse to allow detection of failures almost independent of the initiating mechanism, there are cases for which forewarning is effectively outside the capability of any program. Unpredictable catastrophic events of Types 1 and 4 (meteorite impact, acts of war) are necessarily of this classification. Although it may be prudent to prepare at some stage a contingency plan which could be rapidly implemented to assess the nature and extent of damage in the unlikely event of such an occurrence, such unpredictable events should not receive significant attention during program specification.

A monitoring program should be able to detect and provide early warning of isolation breachment resulting from non-catastrophic Type 4 events. Although man-induced failures such as unathorized drilling or sabotage can best be avoided by good security and management programs, any failures should be sensed by the monitoring program. The intrinsic ability of a monitoring program capable of sensing such man-induced actions is likely to satisfy the general public more than the promised assurance of "security and good management." Both are needed and monitoring is thus an integral part of security.

The bulk of the monitoring system must necessarily be directed toward detecting failures induced by Type 2 or 3 events. Both of these types of events will have received considerable attention during the repository siting and design phases and the degree of monitoring required can be specified only after an evaluation of the relative probability of specific failure mechanisms. With respect to Type 2 events, relatively short term phenomena such as earthquakes, or changes in ground water or surface water regimes must be addressed in some detail. Very long term geologic events which could result in isolation breachment (erosion, glaciation, and uplift due to mountain building) should be treated if only indirectly. Type 3 occurrences should probably receive proportionally greater attention since, in practical consideration of the time frame involved, they represent occurrences which can be predicted by analytical modeling studies and thus provide a baseline against which monitoring system results can be tracked. In this sense, the objectives of the program would be to confirm design assumptions relating to the integrity of the contaimment medium and detect changes in rock properties or contaminent transport.

In summary, within the 4 general categories of failure modes, natura 1 phenomena which may occur independent of the repository (i.e. Type 2 events) and events which may result due to the presence of the repository (i.e. Type 3 events) require primary consideration. The specific failure mode mechanisms which fall into these categories, and which should form the design basis of the overall program should include the following:

1) Inadequate seal between the shaft/borehole plug and the salt;

2) Development of undetected fractures in the host rocks as a result of excavation and backfilling operations; 
3) Fracturing of salt and/or the overlying and adjacent materials as a result of thermal effects;

4) Reactivation of salt diapirism;

5) Increased solution of salt due to disturbance of ground water flow;

6) Unknown geological features e.g. faults, fractures, in the host and/or surrounding rocks which would provide channelways for ground water flow;

7) Undetected and unknown drill holes in the site region.

Whether events are induced by Type 2 or Type 3 occurrences, the monitoring program must be responsive to (1) physical and chemical changes which are associated with events which could lead to future releases of radioactive materlal and (2) actual levels of radionuclides outside of the repository.

\section{B. Parameter Selection}

There are numerous parameters which can provide information on the physica1, chemical, hydrologic, radiologic, and tectonic condition of the facility and environment. These parameters include, but are not 1imited to: local temperature; rock stress and strain; ground water pressure, level, velocity, $\mathrm{pH}-\mathrm{eH}$, conductivity and chemistry; brine movement and chemistry; ground porosity and resistivity and radioactivity. When the values of the measured parameters correspond closely to those predicted from analytical and theoretical considerations, or those measured during operational monitoring, one can be reasonably confident that repository integrity is intact and that no radioactive release has yet taken place or is pending. Significant deviations could, however, suggest pending isolation failure. The degree of alarm and associated action engendered by detection of such deviations would differ significantly depending upon whether deviations are noted in radiological or precursor parameters. Actions associated with observed radioactivity outside the repository would generally necessitate greater immediate concern than those associated with geological/hydrological readings. In any case, it is expected that initial action would consist of an increased level of surveillance in the area in which the deviation was detected.

It is not possible to measure al1 the parameters which could supply information on repository conditions. The parameters which are discussed below are presently considered most significant. The final selection of key parameters for measurement at an actual facility should be based upon site specific characteristics and design criteria, as well as the availability of instrumentation and the state of technology in power supply and telemetry for the buried instruments. Monitoring during the construction and operation phase may reveal as yet unrecognized processes having potential impact on the integrity of the repository. Accordingly, the list of parameters may be expected to increase and the relative importance 
of specific parameters can be expected to change as additional information is gathered.

It is important that parameters defining tectonic, mechanical, and hydrologic stability be monitored before and during the construction and operation phases. In fact, some geological and geophysical monitoring using surface and, if possible, subsurface and borehole instrumentation should be installed as soon as the site has been selected. The data obtained prior to the emplacement of wastes will provide an important data base for later comparison.

\section{Radioactivity Measurements}

Radioactivity is obviously an important parameter because ultimately it is the escape of radioactivity from the repository which is of concern. Detection of radioactivity outside the repository is a direct indication of the status of repository integrity. Other monitored parameters are indirectly indicative of the radiological status of the repository and are of use only if they can be predictive of the future radiological condition of the repository and the surrounding areas.

Radiological data accumulated within the repository could be of use in assessing the integrity of the waste canisters and the migration of radionuclides within the repository. Since the canisters are expected to corrode, and since water contained within the salt is expected to migrate toward the canisters and act as a medium for radionuclide migration within the repository, radiological readings taken within the repository would be more indicative of individual canister integrity than of repository integrity. Accordingly, the utility of radiological data gathered within the repository is uncertain. It is conceivable, that an anticipated change in radiological levels within the repository, correlated with other radiological and non-radiological data gathered outside the repository, may provide meaningful information regarding the integrity of the repository and the need for protertive or corrective actions.

\section{Hydrologica1 Mea surements}

Circulating ground water is considered the most likely means by which radionuclides can reach the biosphere. While the very nature of salt precludes the presence of circulating ground waters within the repository, many lithologies adjacent to the facility could contain significant quantities of ground water. This is particularly true in the case of domal salt. Changes in the ground water conditions could be caused by factors independent of the repository or induced by the presence of the repository.

Fluid movement and pressure in the overlying or adjacent aquifers may be indicative of changes which could affect the repository. Since these aquifers could ultimately be the vehicles for transport of radionuclides to the biosphere, aquifer monitoring is especially germane to the overall program.

Buried radioactive waste may cause an increase in temperature adjacent to 
and above a salt dome. A similar rise in temperature should be expected for burial in bedded sa1t. Ground water measurements outside the periphery of the repository in various water-bearing strata should allow determination of some of the effects of the temperature increase. Measurements of water chemistry (particularly salinity), velocity, and direction would permit determination of any changes in the ground water regime. Similarly, changes in the ground water regime due to climatic and seasonal influences and man-related activities could be detected.

\section{Geologica1/Geophysica1 Measurements}

Establishment of a waste storage facility in bedded and domal salt will affect the virgin stress conditions of the confining 1 ithology and the adjacent strata. Although the facility will be backfilled after storage is complete, voids, to the extent of about 50 percent, may be expected (Office of Waste Isolation, 1977). When combined with the temperature increases resulting from the dissipation of waste heat, significant physical changes in the repository and overlying strata may result.

It has been calculated that, depending upon repository design, an uplift of about four feet could be expected at the surface after a period of 200 years. This uplift would be followed by a subsidence to the original elevation after about 1000 years, with the ultimate subsidence at the surface being on the order of two feet (Blomeke, 1977).

While a degree of movement is expected, it is nevertheless important to monitor the magnitude of the changes. Although such changes are not expected to compromise the integrity of the facility, monitoring of these changes could serve as a basis for correlation with analytical predictions and thus provide an indication that changes in repository conditions were occurring as expected. Among the parameters indicative of these changes, and most susceptible to direct measurement, are uplift and subsidence, strain, and temperature. 
III. CONCEPTUAL APPROACH TO POSTDECOMMISSIONING MONITORING

The conceptual approach to a postdecommissioning monitoring program for a waste repository facility must emphasize the surveillance function of the monitoring system as the system is not intended to be solely an automatic record keeper. Since a major objective of the monitoring system should be to confirm design assumptions relating to the integrity of the containment medium, a proper surveillance monitoring system should possess failure warning capability with sufficient forewarning time to allow corrective action if necessary. Proper surveillance monitoring thus requires timely detection of radioactivity released from the repository and/or any event precursory to a potential radiological release. The establishment of a system with failure warning capability will thus require that considerable attention be given to defining appropriate warning levels, acceptable response times and corresponding action plans. While detailed guidance in these areas is not available at present, the qualitative aspects of a postdecommissioning monitoring program can be addressed. As more detailed information becomes available, specific program features can be further defined.

In providing the basic surveillance functions the monitoring program must rely upon a network of monitoring emplacements located either at the surface, in unplugged boreholes, or buried in the repository and its surroundings to monitor the parameters indicative of repository integrity. An additional approach, establishment of subsurface monitoring galleries, may become desirable depending upon the sensitivity required and relative economic considerations. A general discussion of the relative advantages and disadvantages of each of these approaches is provided in Subsection III A. A preliminary consideration of instrument deployment using a combination of these approaches is contained in Section III B.

\section{A. Monitoring Emplacements}

1. Open Borehole Monitoring

Because of the restrictions on penetrating repository containment, open borehole monitoring would be limited to the subsurface strata overlying the disposal horizon and to the region beyond the three mile buffer zone.* The primary advantage of this monitoring approach is that it allows access to the monitoring equipment thus affording a degree of retrievability and maintainability. In addition, power supply and data transmission problems would be lessened through the use of electrical connections with the surface. These features would allow this phase of the program to be continued for an indefinite time period, subject basically to the continuing maintenance of the borehole and the continuing evaluation of program effectiveness by the governing body. As more sensitive instrumentation is developed, it could be incorporated into the program.

A relative disadvantage of borehole emplacements is that sensing is limited to the subsurface strate above the salt and the confining bed or beyond the

*The zone may be significantly smaller for domal salts. 
buffer region. The extensive area and volume to be monitored can in effect limit the sensitivity which can be, achieved as a result of the small range covered by limited monitor emplacements. This sensitivity can, of course, be increased by increasing the number of monitor emplacements at some economic penalty. The limited range of many of the monitors which can be used may make it economically impossible to provide the kind of complete coverage which would be necessary to monitor non-uniformly distributed effects. This problem could be partially ameliorated by preferentially distributing monitors along zones of known pre-existing weakness. Nonhomogeneous effects are likely to occur along such zones which should be detected prior to decommissioning.

For a repository, a radiological detection system deployed in the region between the repository and the nearest freshwater-bearing aquifer could provide a warning that repository failure has occurred and that radionuclides are migrating toward the aquifer. The degree of early warning provided by such a system would depend upon the sensitivity of the detector, the flow rate of the radionuclides and the distance to the aquifer. The adequacy of any given detector and method of deployment would depend upon the amount of early warning required to take appropriate protective and/or corrective actions.

A special case of borehole monitoring which may be of great significance to a monitoring program, depending upon site characteristics, is direct aquifer sampling. Aquifer sampling could partially solve the problems of providing adequate areal coverage since it could be essentially integrative in nature. Whether radionuclide transport is uniform or in a specific direction along a zone of discontinuity, the point of ultimate discharge to a potential environmental dose pathway would be, in many cases, a freshwater aquifer. Additiona11y since freshwater samples could be extracted and subjected to laboratory analysis, much lower levels of radionuclides could be detected than for in situ monitoring. Provided that adequate warning lead times could be obtained, which depends upon criteria which remain to be established, aquifer sampling could function as a prominent part of a surveillance program.

\section{Buried Monitors}

In this case the monitors would be located in plugged boreholes or in the repository. Due to the constraint on penetrating the confining strata, the monitoring instruments must have power available from sources not communicating with the surface and must have telemetry equipment or alternative schemes for data transmission. The advantage of this system is that it more directly monitors the repository. From the radiological standpoint, the emplacement geometries and resulting sensitivities would afford the longest failure warning lead time in that "abnormal" movement of radionuclides would be sensed sooner than with open borehole or surface instrumentation. In addition, the proximity of the monitoring emplacements to the sources of radioactivity would result in an increased probability of early detection of radioactivity migration for the same number of monitors when compared to other monitoring locations. With such deployment, the path area between emplacements through which the radionuclides could escape undetected would be effectively smaller. 
The primary limitations of this approach are availability of a suitable power source and communication equipment and the inability of equipment to withstand the harsh environment of the repository and/or the sealed borehole. Suitable power supplies and data transmission equipment are not presently available "off-the-shelf" but appear to be developable provided that appropriate resources are committed (Westinghouse, 1976). Among the available power supply candidates, radioisotope thermoelectric generators, similar to those developed in the Space Nuclear Auxiliary Power (SNAP) program appear to be the most promising. Several radioisotopes 2 re suitable for the application, including ${ }^{238} \mathrm{Pu}$ ( 86 year half-1ife), ${ }^{244} \mathrm{Cm}(18.4$ years) and ${ }^{90} \mathrm{Sr}$ (28 years). In particular $238 \mathrm{Pu}$ in conjunction with BiTe or $\mathrm{PhTe}$ as a thermoelectric material has been used successfully for temperature ranges below $250^{\circ} \mathrm{C}$. With regard to telemetry, work performed by Westinghouse (1976) indicates that electromagnetic communication may prove successful with present capability of two-way communication over distances greater than 1200 meters in most types of mine environments.

Although it may not prove to be an absolute necessity, it would be highly desirable to have buried instrumentation available for the time period immediately following decommissioning, particularly for the purposes of model verification and correlation of buried and non-buried instrumentation. Assuming the development of the requisite power supply and telemetry technologies, buried deployment would still realistically be limited to the short term by repository environmental conditions.

\section{Surface Monitoring}

From a failure warning viewpoint, it is expected that surface monitoring would be limited to consideration of geological and hydrological changes in the repository and overlying strata. As discussed in Section IV, seismic, electrical, and displacement instruments located at the surface should be able to provide information on changes in subsurface conditions. If sufficient sensitivity can be achieved, such changes may be considered indicative of events occurring pres.11rsory to radionuclide transport.

Radiological monitoring conducted at the surface would be impact-assessment directed rather than failure-warning directed. While a wide range of presently available radiation detection equipment could be employed to sample air, water, and terrain with extreme sensitivity, such sampling would be a last line in any failure-warning defense since little if any corrective action could be expected. Normally such environmental monitoring would only serve to assess the impact of any releases, rather than forewarning of such releases.

\section{Subsurface Monitoring Galleries}

Since the effectiveness of the radiological monitoring program is hampered by the limited range and numbers of monitors, a considerable improvement in reliability as well as sensitivity could be gained by providing greater areal coverage in the strata overlying (or possibly underlying) the repository and its surrounding salt environment. One relatively simple method of achieving such coverage, aquifer sampling, was discussed previously. A 
second more involved approach would be to establish monitoring galleries at subsurface levels preferably below the overlying aquifers.

The confluence of sampling points within the galleries would certainly diminish the possibility of a bypass of the monitoring network such as may occur between monitoring emplacements with no galleries and if established at sufficient depth it could afford significant forewarning times. The larger the sampling coverage the less the possibility of a bypass.

Whether galleries could indeed be considered as a feasible alternative approach would depend upon the interplay of a number of technical, economic, and regulatory factors. Such basic criteria as previously noted (action levels, required lead times, significant impact, etc.) need to be considered to effect a balance between economics and statistically significant and timely detection.

\section{B. Deployment of Monitors}

In order to gain maximum information for the operation period of the monitoring system, it is likely that a combination of surface, borehole, and buried instruments, with the possible incorporation of subsurface galleries, will be required providing that sensitivities can be obtained. Such a system could provide a three-dimensional picture of the rocks containing and surrounding the isolated waste and of significant radioactivity leaving the repository. In addition, this type of system would supply information for an indefinite period of time, thus maintaining some degree of retrievability of instruments so that future monitoring developments could be incorporated into the program as desired.

It is expected that for the limited time period during which the buried equipment is operational, much information on the behavior of the rock volume could be obtained which should allow an accurate prediction of future rock behavior. The correlation of data obtained from surface, borehole, and buried instruments during this period should allow some prediction of subsurface behavior from surface instrument data. It is unlikely, however, that during a similar time period any radioactivity will migrate from the repository to allow correlation of radiological data from surface and buried instruments.

The eventual layout of instruments at an actual facility must necessarily be tailored to the individual sites. Some of the factors that would influence instrument location are: (1) location in domal or bedded salts; (2) salt dome size and configuration; (3) geology of the salt bed; (4) geology of the overlying and adjacent strata; (5) regional tectonics and structural features; (6) initial hydrologic regime. Instruments measuring parameters which can be predicted from physical processes and modeling; e.g. temperature and fluid incursion, may be most advantageously located in grid patterns within the facility, or where calculations indicate peak intensities, concentrations or gradients. The positioning of some of these instruments must nevertheless take the large and sma11 scale geologic conditions into account, especially where fracturing may permit differential movement and concentration. In general, monitoring of a facility in a salt 
dome would involve a denser coverage of surface and borehole instruments, due to the more "self-contained" nature of a dome. For facilities where bedded salt acts as the confining unit, a similar number of instruments may be used but the "grid" would be spread over a much larger area. Another example of the site specific nature of the program for most of the instruments would be the possible concentration of more monitoring wells in the down dip direction in any aquifer above bedded salt. These would give more information than an equally spaced "grid" of instruments and wells.

It must be stressed that the observation points, or we11s, should be as nearly constant as possible throughout the monitoring program. The position of the wells should in fact be determined during the siting study; and wherever possible, wells originally drilled for siting and construction purposes should be used for the decommissioned phase monitoring program. If new wells are required, they should be located as near as possible to the old wells. The observation points must be properly positioned and sufficiently sensitive to detect significant changes.

Information obtained from the region above the bedded (and domal salts) should be evaluated with respect to control information gathered from a distance away from the isolated waste. This is especially true for any tiltmeter information, to determine if uplift or subsidence is regional or loca1. Laser ranging and ground water information and its radioactivity could also be tied to data gathered beyond the zone of influence of the facility. 


\section{MONITORING TECHNIQUES AND INSTRUMENTATION}

For the most part, techniques and instruments exist for measuring the geological, hydrological, and radiological parameters discussed in Section II as being indicators of repository integrity. Whether these techniques and instruments could be effectively employed in the proposed repository monitoring application can be determined only after a more detailed analysis of the effects associated with the occurrence of potentially significant failure events, and a comparison of these effects with instrument sensitivities under site conditions. In the following sections, the available techniques are discussed in a general manner. It is recommended that a further analysis be carried out to match the sensitivities of these instruments to the expected effects and, when available, to the applicable regulatory criteria.

\section{A. Surface Monitoring}

\section{Geological and Geophysical Techniques}

Geological and geophysical surface instrumentation could be used as part of a monitoring program to observe fracture growth or movement along preexisting discontinuities, changes in the ground water regime, the redistribution of rock stress and strain, and surface uplift and subsidence. Such instrumentation would consist predominantly of seismic equipment, extensometers, tiltmeters, and laser ranging and electrical resistivity equipment (see Table IV-1). These instruments, most of which are used in mining activities and resource exploration programs presently form the basis for well-proven and rellable monitoring techniques.

\section{Seismic Methods}

A surface array of geophones or seismometers can be used to monitor changes in subsurface conditions in two different ways. In the first method ("active" seismic monitoring); seismic waves are artificially generated by exploding small amounts of explosives either at or near the surface or in relatively shallow boreholes. By recording the seismic signals at a number of detectors, one can obtain a fairly accurate picture of the subsurface geology (for example, Dobrin, 1976). Depending on the depth of the waste repository, seismic refraction and/or reflection techniques may be used. Keeping the position of the detectors and the source points fixed, the seismic survey can be repeated at periodic intervals (e.g. every few months) so as to detect physical changes in the subsurface. A comparison of seismic records from each detector position at various times should provide reliable information on where rock conditions have changed within the subsurface environment.

The seismic measurements are generally most sensitive to changes in seismic veloc1t1es. Almost every physical change in rock is accompanied by a change in seismic velocities. Numerous laboratory studies have shown that as rock approaches failure, the velocity changes can become very large (more than 10 percent), especially along certain directions (see, for 


\section{SURFACE MONITORS}

PHÝS ICAL CHAZACTERISTICS

1.

2.

3.

4.

5.

6.

7.

8.

9.

10.

Radioactivity

\section{INSTRUMENT}

Geophones and Energy Source

Seismometers

Vo1tmeters, and other electrical equipment

Tiltmeters

Geodolite

Multi-Wavelength Distance Measuring (MWDM) Device

Ge(Li) Crystal (Nitrogen cooled) Spectrometer - on line or samples

Geiger Mueller Counter - Proportional Counter (alpha and gamma spectrometry)

Scintillation Crysta1 - Spectrometer on line or samples (beta-gamma)

Liquid Scintillation Spectrometer samples 
example, Tocher, 1957 or Gupta, 1973). It is expected that the rock deformation or fracturing accompanying breachment of the waste facility would induce significant velocity changes which could be detected by an array of seismometers. If necessary, a precision of about 1 part in $10^{5}$ can be obtained for in situ velocity measurements by using a specially designed selsmic signal generator together with an analog phase measuring device as the recorder (Aki, et al, 1970 and De Fazio, et a1, 1973). The exact location, spacing and number of sources and detectors would depend on many parameters such as depth of the repository, and the nature and extent of the expected physical changes in rock. The detectors should be permanently fixed and the positions of the source points should also be kept as nearly flxed as possible so that any anomaly detected by one or more detectors can be attributed to a change in the subsurface condition alone.

In the second method of seismic monitoring, microseismic activity or rock noise are measured without the application of an external seismic source. It is now well established that microseismic activity of a characteristic pattern precedes, accompanies, and follows the failure of most rocks. In some instances, sudden violent failures of mine structures known as rock bursts occur in highly stressed zones. Several recent field studies have shown that the stability of underground structures can be evaluated by monitoring microseismic activity at a number of suitably placed detectors (e.g. Hardy and Mowrey, 1976; Hardy, 1975; Blake, 1972; Blake and Leighton, 1969). By observing the seismic wave arrivals at various detector positions one can locate the sources of seismic disturbances. Even if distinct seismic wave arrivals are not observed, an increase in vibration level (due to rock noise) by some detectors will indicate the initiation of rock fracturing in the vicinity of those detectors. If the seismic wave arrivals are distinct and can be timed, one can pinpoint the location of the disturbance and also examine the manner of its development. Such studies have been carried out by McClain (1971) and Bailey (1971) during the seismic mapping of hydraulic fractures.

IL seems therefore that both active and passive seismic monitoring with an array of seismometers on the surface can provide valuable information on changes taking place within the subsurface environment. The seismograph system selected for this purpose should be broad-band so that both externa11y and internally generated seismic signals can be detected and recorded. A microseismic system similar to that developed by the U.S. Bureau of Mines (Blake and Duval1, 1969) should be suitable. This system consists of genphones, 10w-noise preamplifiers, high-gain amplifiers and an FM magnetic tope recorder. The frequency response of the system is flat from 2 to $20,000 \mathrm{~Hz}$ and the dynamic range is greater than $200 \mathrm{db}$. Signals with acceleration levels as low as $2 \mu \mathrm{g}$ can be detected. Such a system, with minor modifications, has successfully been used by Blake (1972) and Hardy (1975).

\section{Electrica1 Measurements}

Monitoring by conventional electrical resistivity equipment can provide usejeful information on changes in some physical properties of the subsurface. Electrical current is applied by conduction to the ground through electrodes 
and the potential drop measured between a second pair of electrodes. Electrical conduction in the majority of rocks is essentially electrolytic. This is because most mineral grains are insulators and conduction is through the interstitial water which is usually present and which invariably contains some dissolved salts. Hence, the resistivity of a formation generally depends on the resistivity of the contained electrolyte and is inversely related to the effective porosity and the degree of saturation. Electrical monitoring is therefore likely to be effective in detecting changes in the ground water regime of the subsurface rocks. Tectonic movements accompanied by opening or closing of cracks and fissures can also induce large changes in electrical conductivity. Periodic monitoring of electrical resistivity could therefore provide useful information on the structural integrity of the waste repository.

The experimental setup used for periodic electrical monitoring can be very similar to that used for active seismic monitoring. The exact numbers of current and potential electrodes in an actual experiment would depend primarily on the depth of repository and the nature of geological subsurface material. Any significant change in subsurface conditions is expected to be accompanied by a change in the electrical conductivity which should be detected by one or more of the potential electrodes. The depth of penetration of electrical measurements can be controlled by varying the spacing between current and potential electrodes. As in the case of seismic monitoring, it is important that all source and detector positions remain fixed so that any changes observed during the monitoring process can be properly interpreted.

\section{Measurement of Ground Displacement}

Sensitive tiltmeters in the site region could be used to detect relative vcrtical movements (such as uplift or subsidence) over the waste site. Geodimeter surveys could be used to determine whether a horizontal component of displacement is occurring in the site region.

Biaxiál LIl tmeters (model TM-1-B) manufactured by Kinemetrics, Inc. are being used in the investigation of Gulf Coast salt domes as prospective sites for the storage or disposal of radioactive waste (Martinez et al, 1976). These tiltmeters are extremely sensitive instruments capable of resolving tilts smaller than $10^{-8}$ radians. The instruments are buried a few feet underground so as to minimize external noise. An array of tiltmeters could be deployed in the repository site region to monitor lucalized regions of relative uplift or subsidence. The array of tiltmeters over a facility in bedded salt should cover a larger areal extent than that over a salt dome, where the movement would be expected to be more localized. In both cases the resultant data need to be compared with regional data to distinguish localized movement from regional movement.

The U.S. Geological Survey has been making accurate geodetic measurements using a Geodolite (Savage et a1, 1976; Savage and Prescott, 1973). I'his is a commercially available electro-optical distance-measuring instrument. A modulated laser beam is projected from the instrument to a remote 
retroreflector from which it is returned to the instrument. This instrument can detect distances with a precision of about 2 parts in $10^{7}$.

More recently, a multi-wavelength distance measuring (MWDM) instrument that utilizes the dispersive nature of the atmosphere has been developed and tested (Slater and Huggett, 1976). The precision of this instrument is a few parts in $10^{8}$ for path lengths of up to $50 \mathrm{~km}$ and temperatures of up to $30^{\circ} \mathrm{C}$.

In summary, geological and geophysical surface instrumentation can indicate movement of the salt caused by thermal expansion or renewed diapiric type movement, and any movement on discontinuities which may be present in the rock strata. In addition, it can detect fracture growth in the rock mass. To make this information of maximum use, an attempt should be made to correlate surface data and that collected from buried instruments to allow a better prediction of subsurface behavior after the failure of the buried instruments.

\section{Radiologica1 Detection}

Since the primary information relating to radioactivity levels at or near the surface will come from the subsurface sensors, there appears to be no pressing need for permanent, automatic sampling of air, soil and surface water activity. Should an envirommental radiological monitoring program be required for regulatory or confirmatory purposes, periodic air, soil and water samples could be taken and analyzed using the detection techniques listed in Table IV-1.

While the sensitivity of the instrumentation varies, radionuclide concentrations which are fractions of the maximum permissible concentrations can be detected by the techniques listed in Table IV-1. It is important to recognize that the sensitivity of the surface sampling techniques to radioactivity concentrations contributed from the repository would be strongly affected by the presence of residual surface contamination resulting from prior surface operation; precautions should thus be taken to minimize such contamination.

B. Open Borehole Monitoring

Geological/geophysical and hydrological studies can be performed in unplugged boreholes employing primarily standard geophysical logging techniques. Many of these technques have been used by the oil industry for exploration purposes since 1927. Detailed discussions of the se techniques can be found in standard references, for example, Kelley, 1973; Schlumberger, 1972, 1974; Pirson, 1970.

\section{Geological and Geophysical Investigations}

The principal geologica1/geophysica1 borehole investigations that could be performed are acoustic, electrical and radioactivity logging (see Table IV-2). 


\begin{tabular}{|c|c|}
\hline NUMBER & $\begin{array}{l}\text { PHYS ICAL CHARACTERIST ICS } \\
\text { TO BE MONITORED } \\
\end{array}$ \\
\hline 1. & Strain in Salt \\
\hline 2. & Ground Water Conductivity \\
\hline 3. & Ground Water $\mathrm{pH}-\mathrm{eH}$ \\
\hline 4. & Ground Water Velocity \\
\hline 5 . & Ground Water Temperature \\
\hline 6. & Ground Water Salinity \\
\hline 7. & $\begin{array}{l}\text { Ground Water Pressures } \\
\text { and Leve1s }\end{array}$ \\
\hline 8. & Temperature \\
\hline 9 . & Fractures \\
\hline 10. & Porosity \\
\hline 11. & Porosity \\
\hline 12. & Porosity \\
\hline 13. & Formation Factor \\
\hline 14. & Fluid Resist $=v i t y$ \\
\hline
\end{tabular}

INSTRUMENT
Multiple-Position Extensometers
Automatically Recording in-Hole
Resistivity Meter
Borehole
Tagged Tracers
Conventional Thermisters
Borehole and laboratory analysis
Transducer Type Multiple Point.
Piezometers.
Platinum Thermocouple
Acoustic Log.
Acoustic Log
Density Log
Resistivity Log
Resistivity Log
Resistivity Log




\section{SUBSURFACE MONITORING}

\section{NUMBER}

15.

16.

17.

18.

19.

\section{PHYSICAL CHARACTERISTICS}

TO BE MCNITORED

\section{Fluid Movement}

Ground Water Radioactivity

Ground Water Radioactivity

Ground Water Radioactivity

Ground Water Radioactivity

\section{INSTRUMENT}

Fluid Movement Logger

Ge(Li) Crystal (Nitrogen cooled)

(Laboratory Instrument)

Geiger Mueller Counter (beta-gamma)

Scintillation Crystal (in-hole or laboratory)

Liquid Scintillation 


\section{Acoustic Logging}

Acoustic logging measures various properties of propagation of sound waves transmitted through a formation and contained fluids in a known distance. A transmitter or transducer produces vibrational sound waves or an elastic wave train. Electronic equipment in the sonde, and recorders at the surface, can measure the velocity, amplitude and periods of the compressional and shear portions of the elastic wave train which has traveled through the rock. The depth of investigation of the log varies between a fraction of a foot to a few feet depending on material penetrated and type of tool used.

The primary use of acoustic logging is to determine porosity. It can also be used to identify faults and fractures. More recent techniques (e.g. Three-D log, Amplitude log) can provide additional useful information on the physical and mechanical properties of rocks encountered by the sensing devices.

\section{Electrica1 Logging}

There are several types of electrical logging which could be used to advantage in a postdecommissioning monitoring program (eg., resistivity $\log$, self-potential $\mathrm{log}$, induction $\log$ ). These $\log s$ provide useful information on electrical properties which can generally be interpreted in terms of the physical, mechanical and hydrological characteristics of adjacent rock units.

Resistivity logging may provide the most useful information of al1 the electrical logging techniques. Resistivity logging devices measure the electrical resistivity of a known or assumed volume of earth and materials under the direct application of an electric current or an induced electric current. These loggings could be used to determine formation resistivity, formation porosity, fluid resistivity and formation factor. The resistivity of a rock depends on the composition of contained water, on the amount of water, and on the shape and length of the interconnected pores. Another potentially useful application of resistivity measurements is the calculation of permeability. Several procedures exist for resistivity logging; the procedure employed during the monitoring phase should be the same as that employed during the pre-construction and construction phases so that the resistivity data can be meaningfully interpreted in terms of changes in the porosity and permeability of the surrounding environment. This could point to the development of a fracture in the rock formation and/or the migration of water in the formation.

\section{Radioactivity Logging}

There are several types of radioactivity logging (e.g. gamma ray logs, neutron $\log s$, density logs) which provide useful information on water content, porosity and permeability of rocks. In the proposed application, density logging may provide the most useful information of all the radioactive logging techniques. 
Density logging measures the average density of formations, including the rock matrix and contained fluids within a short distance from the borehole. Gamma rays from a source in the tool irradiate the formation. The gamma rays are scattered by electrons in the formation around the well borehole, and back-scattered rays are measured with a gamma ray detector located at a specific distance from the source. The intensity of back scattered gamma rays is directly related to the electron density of the formation, which is in turn related to the actual density of the formation and contained fluids. Deviations from the grain, or matrix density of the rock type, generally represent the effect of the density of contained fluids. The depth of investigation is a relatively short distance ( 3 to 6 inches) that is essentially the invaded zone. The primary use of density logs is to determine porosity. Changes in porosity could be an indication of the development of new joints or fractures which in turn may affect ground water movement.

A potential problem with radioactivity loggings is that they may interfere with in situ radiation monitoring instrumentation. Radioactivity loggings may thus be less desirable than the other types of logging, since in effect they may render in situ continuous radiological monitorings ineffective. This potential difficulty could be partially mitigated by restricting radioactivity loggings to specific boreholes.

\section{Hydrological Logging}

Two sets of instrumentation monitoring ground water velocity, temperature, pressure, salinity, $\mathrm{pH}-\mathrm{eH}$, electrical conductivity and radioactivity are forseen. One set could be buried in plugged shafts or boreholes or in the repository itself while the other set could be placed in open boreholes specifically provided for monitoring purposes.

These instruments could be used during the operational phase of the facility and could be replaced and maintained during postdecommissioning monitoring. It is anticipated that the number and placement of the boreholes will have been determined during the siting and operating phase by defining ground water flow fields and the location of fracture concentrations, taking into account any anomalous information on ground water recognized previously.

\section{Fluid Movement Logging}

Fluid movement logging includes all techniques for measuring natural and/ or artificially induced flow within a single borehole. Data on in-hole flow is related to well construction, differences in head, and the relative magnitude of permeability of water-bearing units open to the we11. Devices used to measure the vertical and horizontal components of flow in a single we11 include impeller flowmeters, thermal.flowmeters and various systems for injecting and measuring the flow of radioactive and chemical tracers. As with resistivity logging, fluid movement logging techniques and instruments would be similar to those employed during the pre-construction phase so that the data can be understood in terms of seasonal. variations and therefore properly interpreted. 
Ground Water Conductivity

Ground water conductivity could be continuously monitored and automatically recorded using either existing in-hole resistivity devices or sensors which are modified from commercially available equipment such as that presently imported by Nimbus Instruments. Conductivity sensors can be installed in open boreholes, plugged boreholes or plugged shafts.

Ground Water $\mathrm{pH}$ and $\mathrm{eH}$

Ground water $\mathrm{pH}$ and eH could be determined using electrode technology. A manufacturer of such electrodes is Orion Research Incorporated. These devices may be installed in open as well as in plugged boreholes and shafts.

\section{Ground Water Velocity}

Ground water velocity can probably be best measured using techniques of tagged tracers. The potential problem with this technique is that it could interfere with on-line radiation monitoring, thus requiring the use of more sensitive, and possibly less reliable, radioactivity detection equipment.

\section{Ground Water Temperature}

Ground water temperature could be monitored at numerous locations using automatic recording devices coupled with conventional thermistors. The thermistors are potentially suitable for placement in open or plugged boreholes and shafts. Data collected from such systems could be useful in detecting excessive temperatures which may increase the amount of dilution of salt and may alter ground water flow by convection.

\section{Ground Water Salinity}

Ground water salinity could be monitored on an automated basis using electrode technology. The electrodes, as can be modified, are suitable for installation in open or plugged boreholes or shafts. In addition, ground water samples could be collected periodically and subjected to a detailed water analysis in the laboratory.

\section{Ground Water Pressures and Levels}

Ground water pressures and levels could be automatically recorded utilizing transducer-type multiple point piezometers such as those presently manufactured by the slope Indicator Company. These piezometers, modified for the environment in which they are expected to operate, will be suitable for installation in open or plugged boreholes and shafts.

\section{Radiological Logging}

Radiation monitors can be selected to detect either alpha, beta or gamma radiation. Since gamma radiation has the greatest range it is considered most suitable for the present application. Two detection schemes are available. One scheme relies on direct detection in the borehole. For direct detection, sensor selection is essentially limited to the use of either a gamma scintillation crystal or a gamma Geiger Mueller Counter. The second scheme would rely upon ground water as aspiration sampling with the detector located at the surface, possibly in a laboratory where counting or analysis is done. 


\section{Gamma Scintillation Crystal Detector - Spectrometer}

The availability of off-the-shelf gamma scintillation detection equipment capable of withstanding the repository environment is cited by an equipment manufacturer (Harshaw). These assemblies are widely used in we11 logging applications and feature one-piece stainless steel housings. Sensitivity of this instrumentation is sufficient to detect $10^{-7}$ or less $\mu \mathrm{Ci} / \mathrm{gm}$ of enveloping media.

\section{Geiger Mueller Counter}

Off-the-shelf heavy duty, stainless steel Geiger Mueller (GM) tubes are readily available for use in temperatures up to $300^{\circ} \mathrm{F}$; special tubes go as high as $700-1000^{\circ} \mathrm{F}$.

The ability of a GM tube to stand up to high temperature and shock depends on the materials selected for insulation, and cathode coating, the nature of the gas filler, and the geometric disposition of the anode wire (whether fixed at both ends or cantilevered). Although the GM tube has only gross counting capability and as such suffers by comparison with scintillation crystal detection, it compares favorably with the scintillation crysta 1 detector in this application due to its more rugged shock-proof nature. Sensitivities achieved through GM monitoring will be comparable to those achieved with scintillation detectors. GM detectors also have low background noise.

\section{Semiconductor Detectors}

Increased sensitivity as well as superfor resolution and identification of radionuclides can be achieved with a semiconductor (solid state) detection system. The currently avallable detectors, such as germanium drifted lithium (Geli), are effectively limited to laboratory-1ike applications, which require that a sample be delivered from the borehole to the sampling chamber. Recent developments in intrinsic semiconductor detectors capable of surviving long time loss of cryogenic cooling show promise for potential future application of this type of detector directly. in the borehole.

\section{Monitoring of P1ugged Boreholes}

Boreholes that penetrate the salt beds or domes will be sealed after decommissioning of the waste facility to insure continued isolation. These sealed holes could, upon failure, give rise to a direct route to the repository and thereby represent a potentially significant failure mode. It may therefore be necessary to monitor the integrity of the borehole plugs by placing instruments within the material used as the plug. These instruments could also be used to monitor changes in the volume of rock enclosing the radioactive waste. Methods of monitoring plugged boreholes have been summarized by West1nghouse (1976). They conclude that existing borehole logging instruments can be adapted for use as buried instruments; and limitations on measurements in sealed boreholes are more likely to be found in auxiliary subsystems such as power supply and communications rather than in the instruments themselves. The four systems having the greatest potential for use in this application are geophones, the density monitor, the water hydrocarbon detector and the acoustic signature monitor. In addition to the 
above instruments, an array of total pressure cells could be installed to monitor stress changes in back-filled or confining rocks.

\section{Monitoring in the Repository}

Instruments buried near the waste in the salt unit for geological and hydrological monitoring could include, in addition to those included in Section IV C, extensometers, temperature sensors, triangular total pressure cell arrays and seismometers (Table IV-3). While their life expectancy may only be relatively short term, these instruments could provide necessary direct information on the behavior of the storage factlity during the operational lifetimes of these instruments; this information could be useful in calibrating surface monitors which would remain operational after the failure of the buried packages.

1. Geological and Hydrological Monitoring

\section{Extensometers}

Monitoring of salt movement after decommissioning the facility could be accomplished by use of tiltmeters on the surface, extensometers installed in boreholes from the surface, and continued use of grouted-in borehole extensometers buried near the wastes.

Utilizing currently available equipment, movement in the salt near the waste canisters could be monitored. Borehole extensometers appear to be the best instruments currently available for monitoring strain in the salt. Stress meters and other pressure cells are not very successful in salt due to the plasticity of salt, especially at elevated temperatures (Bradshaw and McClain, 1971).

During the operation phase, multiple-position borehole extensometers could be placed in boreholes penetrating the overlying material (oriented perpendicular to the roof of the facility) and into the salt surrounding the mine (oriented perpendicular to the walls of the facility). The length of the boreholes would depend on the design of the mine, but could be on the order of 100-150 feet, especially if the same holes are to be used for postdecommission monttoring.

Terrametrics Incorporated, Golden, Colorado is one of the firms marketing a multiple position borehole extensometer (MPBX). This patented extensometer measures the relative displacement of borehole anchors which are mechanically fixed to rock units along the axis of the drill hole. . The MPBX consists of the sensor head which is installed at the collar of the drill hole and eight borehole anchors which are connected to the sensor by stainless steel measuring wires. The buried extensometers should be grouted-in to increase the longevity of the instrument. These instruments can continuously monitor strain changes in the salt. Depending on the instrument, sensitivity may be of the order of $0.012 \mathrm{~mm}$ with an accuracy of about. 5 perrent.

Employment of extensometers, and the required array pattern, is site-specific 
TABLE IV-3

BURIED MONITORS

\begin{tabular}{|c|c|c|}
\hline NUMBER & $\begin{array}{l}\text { PHYSICAL CHARACTERISTICS } \\
\text { TO BE MONITORED } \\
\end{array}$ & INSTRUMENT \\
\hline 1. & $\begin{array}{l}\text { Physica1 Properties of } \\
\text { Rocks }\end{array}$ & Geophones and Energy Sources \\
\hline 2. & Microseismicity & Seismometers \\
\hline 3. & Fluid Movement & Water/Hydrocarbon Detector \\
\hline 4. & Fractures & Geophones \\
\hline 5 . & Therma 1. Expansion & Density Log \\
\hline 6. & Fractures & Acoustic Signature Log \\
\hline 7. & Movement in $\mathrm{Salt}$ & Deflectometers \\
\hline 8 . & Strain in Salt. & Multiple-Position Extensometers \\
\hline 9. & $\begin{array}{l}\text { Movement in Faults and } \\
\text { Shear Zones }\end{array}$ & $\begin{array}{l}\text { Multiple-Position Deflectometers } \\
\text { and Shear-Strip }\end{array}$ \\
\hline 10 . & Temperature & Platinum Thermocouple \\
\hline 11. & Radiation & GM Tubes \\
\hline 12. & Radiation & Scintillation Detectors \\
\hline
\end{tabular}


and a function of the design. Extensometers constructed out from the four sides and the top of the facility may give adequate information on salt movement. It will be of paramount importance to measure possible movements along pre-existing zones of weakness.

Faults and shear zones are sometimes encountered during salt mine excavation, as in International Salt Company's Cleveland, Ohio mine, and at the Restoff, New York mine (D'Appolonja, 1976). The monitoring system should thus include surveillance of these discontinuities in case of renewed movement within any of the zones. A number of systems can be used to monitor movement in these zones, including multiple position borehole deflectometers and shear-strip failure locators grouted into boreholes crossing the shear zones.

\section{Seismic Mea surements}

Both active and passive seismic monitoring as described earlier for surface monitoring can be adapted to include detectors at depth. A three-dimensional array of detectors can provide much more accurate information than a two-dimensional array. If possible, a number of detectors should, therefore, be located at various depths and the seismic records examined. The presence of even a few subsurface detectors will also be helpful in obtaining a more detailed and accurate knowledge of the seismic velocities so that the number of seismic events during "passive" monitoring can be accurately pinpointed and followed in time.

\section{Temperature Measurements}

Temperature is one of the most critical monitoring parameters; it is also relatively easy to measure. Analytical and numerical predictions of the temperature distribution throughout the backfilled repository over specified time periods can be developed provided the energy sources embedded in the repository are known and reconsolidation rates and their effects on thermal properties can be determined. Any measured deviation in the expected temperature distribution could be cause for concern.

In specifying instruments for temperature measurement in this application, severa 1 points must be considered:

1) The capability of measuring temperatures of several hundred degrees, centigrade;

2) The possibility of structural damage to the instrument by creep and sudden rock movements; and

3) The corrosive effects of localized concentrations of brine and fluids.

Thermocouples may be suitable for use in the repository environment. It would be advisable to encapsulate the sensing thermocouple junction, like al1 other buried equipment, in borosilicate glass or some other corrosion resistant material. An absolute temperature measurement using a resistive 
device may also prove suitable. The temperature measuring devices should be placed in the repository at locations where the analytical methods have predicted the most closely linear temperature gradient.

\section{Radiological Measurements}

Buried radiological instrumentation could be used in thel short term to detect radioactivity in, the salt surrounding the repository. The only sufficiently reliable monitors which can currently be utilized for this application are the GM tubes and scintillation detectors described previously. As discussed in Section III, the sensitivity of these instruments coupled with the lesser dilution of the radionuclides when detected at these points, makes monitoring at these locations desirable even if only for a limited time period. 


\section{SUMMARY AND CONCLUSIONS}

The development of a postdeconmissioning monitoring program for a waste repository in rock salt will require a detailed evaluation of monitoring techniques and instrumentation, site-specific characteristics, facility design criteria, and analytical modeling results predicting facility response to external and/or internal stimuli. These technical considerations must be balanced, in an iterative process, with economic factors and regulatory criteria developed to provide for the protection of public health and safety. The following qualitative conclusions developed during the course of the present study can serve as a basis for this more detailed evaluation.

1) Postdecommissioning surveillance should be composed of essentially two types of monitoring - monitoring of geological and hydrological parameters which may be indicative of potential radionuclide releases in the future, and monitoring of radloactivity levels which are directly indicative of repository failure occurring sometime in the past.

2) A monitoring program cannot forewarn of all events which could potentially compromise the integrity of the repository. Noncatastrophic natural phenomena which may occur independently of the existence of the repository and events which may result due to the presence of the repository require primary consideration in establishing a monitoring program. For practical considerations, these latter events should receive proportionally greater attention since they represent occurrences which can be predicted by analytical modeling studies and thus provide a baseline against which monitoring results can be tracked.

3) It is desirable, particularly during the initial decommissioned period when model confirmation is desired and when correlation between surface and buried instrumentation can be accomplished, to monitor several parameters to determine the physical, chemical, hydrological, radiological and tectonic condition of the facility and the immediate geologic enviromment. These parameters might include radioactivity, temperature, rock stress and strain, porosity, electrical resistivity, formation factor, and ground water parameters such as salinity, pressure, level, velocity, porosity and $\mathrm{pH}-\mathrm{eH}$. The final selection of the parameters for measurement should be based upon site-specific characteristics and design criteria, as well as the availability of instrumentation and the state of technology in power supply and telemetry.

4) To gain maximum information for the operational period of the monitoring system, a combination of surface, borehole, and buried instrument packages is recommender. While it appears feasible, with the cummllument of the appropriate resources, to develop adequate power and communication systems to allow the deployment of buried monitors in the repository region, such deployment 
would in reality be limited to a short term period after decommissioning due to the harsh environmental conditions to which equipment would be exposed. For this reason surface and open borehole instrumentation must be relied upon to provide effective information in the long term. The expected effectiveness of the various elements of the proposed system for short term and long term periods after decommissioning are summarized in Tables V-1 and V-2.

5) In order to increase the effectiveness of a monitoring program constricted by 1 imited borehole emplacements, it may be desirable to establish monitoring galleries in the strata overlying (or possibly underlying) the repository and its surrounding salt environment. Whether such galleries could be considered as a feasible alternative approach would depend upon the interplay of technical, economic, and regulatory factors.

6) Depending upon site characteristics, aquifer sampling could be of great significance to a monitoring program. Such sampling could partially solve the problems associated with providing adequate areal coverage. The utility of aquifer sampling will depend greatly upon whether adequate warning lead times can be achieved.

7) Actual instrument deployment should be site-specific for most of the parameters. Instruments measuring parameters which can be predicted from physical processes and modeling may be located in grid patterns within the facility, or where calculations indicate peak intensities or concentrations, or quasi-linear gradients.

Based upon the results of the present study, the following recommendations are made:

1) Because of the important role that regulatory criteria will play in determining the objectives of a monitoring program, steps should be taken to interface with regulatory bodies responsible for developing such criteria.

2) To the extent feasible, observation points and wells used for a monitoring program should be the same as those established during the siting and operational phases of the facility, to provide a "long term" data base for comparison. Consideration should therefore be given to a monitoring program and the placement of observation points similar to the proposed program during the siting study and the early phase of operation.

3) A monitoring program should be developed as soon as possible after a specific site is chosen and the design criteria for the facility have been finalized. This program should consider the resulto of the accurate modeling of the designed factilty. 


\begin{tabular}{|c|c|c|c|c|}
\hline \multirow[b]{2}{*}{ Domain } & \multicolumn{2}{|c|}{ Short Term $(1-10 \mathrm{Yr})$} & \multicolumn{2}{|c|}{ Long Term $(10-100 \mathrm{Yr})$} \\
\hline & $\begin{array}{c}\text { Geologic or } \\
\text { Hydrologic Signal } \\
\end{array}$ & $\begin{array}{l}\text { Radiologic } \\
\text { Signal }\end{array}$ & $\begin{array}{c}\text { Geologic or } \\
\text { Hydrologic Signal } \\
\end{array}$ & $\begin{array}{l}\text { Radiologic } \\
\text { Signal } \\
\end{array}$ \\
\hline $\begin{array}{l}\text { Within } \\
\text { Repository }\end{array}$ & Probably effective 1 & - & Probably effective & - \\
\hline $\begin{array}{l}\text { Open } \\
\text { Borehole }\end{array}$ & Probably effective & $\begin{array}{l}\text { Probably effective } \\
\text { for potential en- } \\
\text { vironmental re- } \\
\text { leases having } \\
\text { C/MPC index greater } \\
\text { than unity }\end{array}$ & Probably effective & $\begin{array}{l}\text { Probably effective } \\
\text { for potential en- } \\
\text { vironmental re- } \\
\text { leases having } \\
\text { C/MPC index greater } \\
\text { than unity }\end{array}$ \\
\hline $\begin{array}{l}\text { Plugged } \\
\text { Borehole }\end{array}$ & Probably effective 1 & Probably effective 1 & $\begin{array}{l}\text { Probably ineffec- } \\
\text { tive }\end{array}$ & $\begin{array}{l}\text { Probably ineffec- } \\
\text { tive }\end{array}$ \\
\hline Enviroment & Probably effective & $\begin{array}{l}\text { Probably effective } \\
\text { for failure warn- } \\
\text { ing setpoint at } 1 \% \\
\text { of allowable } \\
\text { C/MPC }\end{array}$ & Probably effective & $\begin{array}{l}\text { Probably effective } \\
\text { for failure warn- } \\
\text { ing setpoint at } 1 \% \\
\text { of allowable } \\
\text { C/MPC }\end{array}$ \\
\hline $\begin{array}{l}\text { Combinel } \\
\text { System } \\
\text { Effectiveness }\end{array}$ & $\begin{array}{l}\text { Probably effective - } \\
\text { nal has corroboration }\end{array}$ & $\begin{array}{l}\text { failure warning sig- } \\
\text { capability }\end{array}$ & $\begin{array}{l}\text { Probably effective } \\
\text { be placed probably } \\
\text { environment - monit }\end{array}$ & $\begin{array}{l}\text { heavy reliance wil } \\
\text { open boreholes and } \\
\text { ing systems }\end{array}$ \\
\hline
\end{tabular}

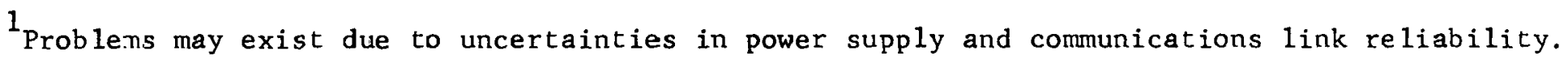




\section{FAILURE WARNING SYSTEM EFFECTIVENESS}

ACCIDENT MODE FAILURES

\begin{tabular}{|c|c|c|}
\hline \multirow[b]{2}{*}{ Domain } & \multicolumn{2}{|c|}{ Short Term $(1-10 \mathrm{Yr})$} \\
\hline & $\begin{array}{c}\text { Ceologic or } \\
\text { Hydrologic Signal } \\
\end{array}$ & $\begin{array}{c}\text { Radiologic } \\
\text { Signal } \\
\end{array}$ \\
\hline $\begin{array}{l}\text { Within } \\
\text { Repository }\end{array}$ & Prcbably effective ${ }^{1}$ & - \\
\hline $\begin{array}{l}\text { Open } \\
\text { Borehole }\end{array}$ & $\begin{array}{l}\text { Probably effective } \\
\text { (dependent upon } \\
\text { accident) }\end{array}$ & $\begin{array}{l}\text { Uncertain - effec- } \\
\text { tiveness is highly } \\
\text { contingent to moni- } \\
\text { toring geometry em- } \\
\text { placements espec- } \\
\text { ially for localized } \\
\text { accident-induced } \\
\text { failure event }\end{array}$ \\
\hline $\begin{array}{l}\text { Plugged } \\
\text { Bcrehole }\end{array}$ & $\begin{array}{l}\text { Probably effective } \\
\text { (dependent upon } \\
\text { accident) }\end{array}$ & $\begin{array}{l}\text { Probably ineffec- } \\
\text { tive for localized } \\
\text { accident-induced } \\
\text { failure }\end{array}$ \\
\hline $\begin{array}{l}\text { Combined System } \\
\text { Effectiveness }\end{array}$ & \multicolumn{2}{|c|}{$\begin{array}{l}\text { Probably effective for indirect indica- } \\
\text { tors such as tritium and radon but un- } \\
\text { certain for direct radiation monitoring } \\
\text { emplacements }\end{array}$} \\
\hline
\end{tabular}

\begin{tabular}{ll}
\multicolumn{1}{c}{ Long Term $(10-100 \mathrm{Yr})$} \\
$\begin{array}{c}\text { Geologic or } \\
\text { Hydrologic Signal }\end{array}$ & \multicolumn{1}{c}{$\begin{array}{c}\text { Radiologic } \\
\text { Signal }\end{array}$} \\
$\begin{array}{l}\text { Probably ineffec- } \\
\text { tive }\end{array}$ & - \\
$\begin{array}{l}\text { Probably effective } \\
\text { (dependent upon } \\
\text { accident) }\end{array}$ & $\begin{array}{l}\text { Uncertain (same } \\
\text { condition as for } \\
\text { short term }\end{array}$ \\
$\begin{array}{ll}\text { Probably effective } & \text { Probably ineffec- } \\
\text { (dependent upon } & \begin{array}{l}\text { tive for localized } \\
\text { accident) }\end{array} \\
\text { failure }\end{array}$ \\
$\begin{array}{ll}\text { Probably effective for indirect indica- } \\
\text { tors but uncertain for direct radiation } \\
\text { monitoring emplacements }\end{array}$
\end{tabular}




\section{REFERENCES}

Aki, K., DeFazio, T., Reafenberg, P. and Nur, A., 1970, An Active Experiment with Earthquake Fault for an Estimation of the In Situ Stress, Seismological Soc. of Amer., Bul1. V. 60, p. 1315-1336.

Bailey, J.R., 1971, Century Geophysical Corporation Seismic Monitoring Report to Oak Ridge National Laboratory, January 19, 1971.

Bishop, W.P. and Miraglia, F.J. Jr., (eds), 1976, Environmental Survey of the Reprocessing and Waste Management Portions of the LWR Fuel Cycle, NUREG-0116 (Supp. 1 to WASH-1248).

Blake, W., 1972, Rock Burst Mechanics, Quarterly of Colorado School of Mines, Vo1. 67, No. 1.

Blake, W. and Leighton, F., 1970, Proceedings, Eleventh Symposium on Rock Mechanics, Berkeley, 1969, American Institute of Mining, Metallurgical, and Petroleum Engineers, p. 429-443.

Blake, W. and Duva11, W.I., 1969, Transactions, Society of Mining Engineers, Vo1. 244, p. 288-290.

Blomeke, J.0., 1977, 1972 Preliminary Safety Analysis Report Based on a Conceptual Design of a Proposed Repository in Kansas. ORNL/TM-5764.

Bradshaw, R.L. and McClain, W.C., 1971, Project Salt Vault: A Demonstration of the Disposal of High-Activity Solidified Wastes in Underground Salt Mines, ORNL-4555.

Claiborne, H.C. and Gera, F., 1974, Potential Containment Failure Mechanisms and Their Consequences at a Radioactive Waste Repository in Bedded Salt in New Mexico, ORNL-TM-4639.

D'Appolonia, 1976, Preliminary State-of-the-Art-Survey: Mining Techniques for Sa1t and Other Rock Types, Y/OWI/SUB-76/16515, Office of Waste Isolation, Oak Ridge, Tennessee.

DeFazio, T.L., Aki, K. and Alba, J., 1973, Solid Earth Tide and Observed Change in the In Situ. Seismic Velocity, Journal of Geophysical Research, v. 78, p. 1319-1322.

Dobrin, M.B., 1976, Introduction to Geophysical Prospecting, McGraw Hil1, New York.

Gera, F., 1975, Geochemica1 Behavior of Long-1ived Radioactive Wastes. ORNL -TM-4481.

Gera, F. and Jacobs, D.G., 1972, Considerations in the Long-term Management of High-leve1 Radioactive Wastes. ORNL-4762. 


\section{REFERENCES (Cont'd)}

Gupta, I.N., 1973, Seismic Velocities in Rock Subjected to Axial Loading Up to Shear Fracture, Journal of Geophysical Research, Vo1. 78, p. 69366942 .

Hardy, H.R., Jr., 1975, Evaluating the Stability of Geologic Structures Using Acoustic Emission, ASTM, STP 571, p. 80-100.

Hardy, H.R., Jr., and Mowrey, G.L., 1976, Study of Microseismic Activity Associated with a Long-Wall Coal Mining Operation Using a Near-Surface Array, Engineering Geology, Vol. 10, p. 263-281.

Kelley, D.R., 1973, A Summary of Major Geophysical Logging Methods (Second Printing): Penn. Geol, Survey, 4th Series, Bu11, MG1.

Martinez, J.D., et al, 1976, An Investigation of the Ut1l1ty of Gulf Coast Salt Domes for the Storage or Disposal of Radioactive Waste, ORNL-SUB4112-25, Oak Ridge National Laboratory, Oak Ridge, Tennessee.

Office of Waste Isolation, 1977, NWTS Program Progress Report, October 1, 1976 to September 30, 1977, Y/OWI-9 (to be published).

Pirson, S.J., 1970, Geologic Well Log Analysis, Gulf Publishing Company, Houston, Texas, $370 \mathrm{p}$.

Savage, J.C., Spieth, M.A. and Prescott, W.H., 1976, Preseismic and Coseismic Deformation Associated with the Hollister, California, Earthquake of November 28, 1.974, Journal of Ceophysical Research, Vo1. 81, p. 3567-3574.

Savage, J.C. and Prescott, W.H., 1973, Precision of Geodolite Distance Measurements for Determining Fault Movcments, Journal of Geophysicàl Research, Vo1. 78, p. 6001-6008.

Schlumberger Ltd., 1972, Log Interpretation - Principles, Schlumberger Ltd., New York.

Schlumberger Ltd., 1974, Log Interpretation - Applications, Schlumberger Ltd., New York.

Slater, L.E. and Huggett, G.R., 1976, A Multiwavelength Distance-Measuring Instrument for Geophysical Experiments, Journal of Geophysica1 Research, Vol. 81, p. 6299-6306.

Tocher, D., 1957, Anisotropy in Rocks Under Single Compression, EOS Trans. Amer, Geophys, Union, Vol. 38, p. 89-94.

Westinghntise, 1976, A Syetcmo Analysis of InsLrumentation for In Situ Examination of Rock Properties, WANL-TME-2877, Westinghouse Electric Corporation, Pittsburgh, Pennsylvania. 
REFERENCES (Cont' $d$ )

Zerby, C.D., 1976, The National Waste Terminal Storage Program, Y/OWI-TM- 1.

ADDITIONAL REFERENCE SOURCES

Alternatives for Managing Wastes from Reactors and Post-Fission Operations in the LWR Fue1 Cycle, Volumes 2, 3, 4, ERDD-76-43.

Oak Ridge National Laboratory, Site Selection Factors for the Bedded Salt Pilot Plant, 1973, ORNL-TM-4219.

Parsons Brinckerhoff Quade and Douglas, Tnc., 1976, Waste Isolation Facility Description Bedded Salt, Y/OWI/SUB-76/16506.

Proceeding of the International Symposium on the Management of Wastes from the LWR Fuel Cycle, 1976, Conf.-76-0701.

Space Power Systems Advanced Technology Conference, 1966, NASA SP-131.

Witherspoon, P.A. (ed), 1977, Summary Review of Workshop on Movement of Fluids in Largely Impermeable Rocks, Y/OWI/SUB-77/14223. 